Research Article

\title{
Evaluation of Contaminated Water Treatment on the Durability of Steel Piles
}

\author{
Hussein Kareem Sultan $\mathbb{D}^{1}{ }^{1}$ Hussein Yousif Aziz, ${ }^{1}$ Baydaa Hussain Maula, ${ }^{2}$ \\ Ali A. Hasan, ${ }^{1}$ and Wadhah A. Hatem ${ }^{2}$ \\ ${ }^{1}$ College of Engineering, University of Al-Muthanna, Samawah, Iraq \\ ${ }^{2}$ Middle Technical University, Institute of Technology, Baghdad, Iraq \\ Correspondence should be addressed to Hussein Kareem Sultan; hussein.ksz@mu.edu.iq
}

Received 20 December 2019; Revised 2 October 2020; Accepted 24 October 2020; Published 11 November 2020

Academic Editor: Claudio Mazzotti

Copyright (c) 2020 Hussein Kareem Sultan et al. This is an open access article distributed under the Creative Commons Attribution License, which permits unrestricted use, distribution, and reproduction in any medium, provided the original work is properly cited.

\begin{abstract}
The most common effluent created by the oil industry is oily wastewater. This produced water (PW) corrodes the steel piles in the infrastructure of bridges, which shortens their service life. It is important to remove organic content in PW to prevent this outcome. Samples from the Ahdab oil field were used in this study. Two catalysts were selected: zinc oxide ( $\mathrm{ZnO})$ and titanium dioxide $\left(\mathrm{TiO}_{2}\right)$ with photo presence as an energy source. The results were organic elimination of $96.4 \%$ and $93.4 \% \mathrm{using} \mathrm{ZnO}$ and $\mathrm{TiO}_{2}$, respectively. The experimental conditions were $\mathrm{pH}=3$ and an irradiation time of $120 \mathrm{~min}$. Due to the ability of $\mathrm{ZnO}$ to adsorb high amounts of organic content from PW, there was an increased elimination of organic content. Hence, the maintenance of steel piles durability is a good alternative to approach the goals of this study. The results of the study demonstrated that the organic adsorption on a catalyst agent reinforced in nonappearance of radiation photo is insignificant.
\end{abstract}

\section{Introduction}

The major environmental and economic problem caused by oil and gas manufacturing factories is the production of oily wastewater $[1,2]$. Usually, the wastewater produced is more than the treated crude oil volume, within $0.4-1.6$ folds $[3,4]$. The produced water (PW) must be treated properly before being released to reservoirs to avoid damaging the environment. Properly treated water can be used for other purposes and reduce water flooding $[5,6]$. The significant quantities of polluted PW that are regularly released into the environment make the treatment methods of great importance, requiring suitable treatments that can remove contaminants that are present in many of these manufacturing streams. These streams are problematic because of the high concentrations of organic content in PW [7]. Furthermore, there are stringent environmental rules that govern how $\mathrm{PW}$ is sent into tanks [8]. Some of the chemical compounds released due to human activities are difficult to remove through PW treatments and are eventually deposited in the environment $[9,10]$. Many researchers raise concerns about PW treatment meeting environmental rules and being reused and recycled when possible $[7,11]$. Numerous diverse methods exist for oil-water emulsions separation, such as adsorption [12, 13], ultrafiltration [14], biological processes [15, 16], and chemical coagulation [17, 18]. However, these techniques do have some limitations and drawbacks. For example, activated carbon adsorption can change the phase of contaminants without eliminating them, leading to additional contamination problems. In biological treatment processes, there are likewise many disadvantages including slow reaction rates, activated sludge disposal, and temperature control [19]. None of these treatment approaches are sufficient to reduce the most tenacious soil contaminants to satisfactory levels. Contaminated water reduces the service life of steel piles due to the interaction of some compounds with steel that leads to erosion of steel sections. Resultantly, steel piles can be corroded so extensively that the bridge life is significantly affected, as shown in Figure 1 [20]. 


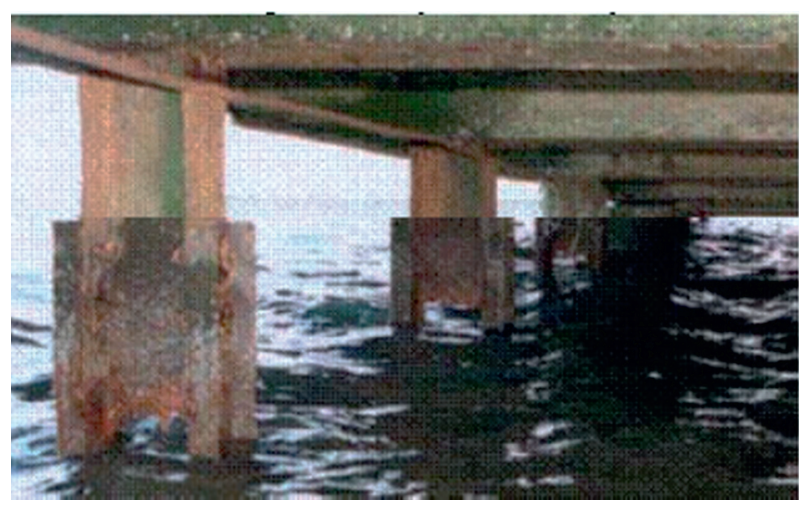

FIgure 1: Corrosion of steel piles [20].

Owing to the low permeability of reactive powder concrete [21, 22], corrosion of steel reinforcement can be prevented or substantially minimized by using it in contaminated water.

In order to reduce the factors affecting the durability of the steel piles, an additional treatment stage is frequently needed. Advanced oxidation processes (AOPs) might be performed when PW contains high chemical stability and is not biodegradable. This method can produce $\mathrm{CO}_{2}$ and inorganic compounds [23]. AOPs are usually applied using two methods: photochemical and nonphotochemical. The photochemical oxidation usually includes homogenous processes such as UV/hydrogen peroxide, vacuum UV photolysis, UV/ozone, photoFenton, UV/ozone/hydrogen peroxide, and heterogeneous processes such as photocatalysis. Nonphotochemical oxidation comprises ozonation at high $\mathrm{pH}$ Fenton and Fenton-like and ozone/hydrogen peroxide processes [24]. The aim of this treatment is the generation of free hydroxyl radical $(\mathrm{OH})$, a highly reactive, nonselective oxidizing agent that can abolish even the recalcitrant contaminants [25]. The overall aim of this study is to remove organic content from the contaminated soil of the Al-Ahdab oil field in Iraq using photocatalytic oxidation processes. The first aim is to find the optimal catalyst agent dosage. The second is to study the parameters that affect the photocatalytic process performance, including $\mathrm{pH}$ and irradiation time.

\section{Materials and Methods}

2.1. Materials. Titanium dioxide $\left(\mathrm{TiO}_{2}\right)$, zinc oxide $(\mathrm{ZnO})$, sodium hydroxide $(\mathrm{NaOH})$, and sulfuric acid $\left(\mathrm{H}_{2} \mathrm{SO}_{4}\right)$ from Merck (India) and distilled water were used in this research work. The solution's $\mathrm{pH}$ was adjusted with $1 \mathrm{~N} \mathrm{H}_{2} \mathrm{SO}_{4}$ or $1 \mathrm{~N}$ $\mathrm{NaOH}$.

2.2. Produced Water. Produced water was collected from the Al-Ahdab oil field in Iraq. The PW was filtrated to eliminate solids and kept at $5^{\circ} \mathrm{C}$ to maintain PW characteristics (Table 1).
TABLE 1: PW characteristics.

\begin{tabular}{lc}
\hline Parameter & Value \\
\hline Organic & $142.51 \mathrm{ppm}$ \\
Turbidity & $110.4 \mathrm{NTU}$ \\
$\mathrm{pH}$ & 6.85 \\
Solution oxygen concentration & $0.055 \mathrm{ppm}$ \\
Specific gravity & 0.994 \\
Conductivity & $72541.64 \mu \mathrm{s} / \mathrm{cm}$ \\
TSS & $21.2 \mathrm{ppm}$ \\
$\mathrm{TDS}$ & $46426.65 \mathrm{ppm}$ \\
Viscosity & $1.104 \mathrm{mPa} / \mathrm{S}$ \\
$\mathrm{Fe}$ & $0.33 \mathrm{ppm}$ \\
$\mathrm{SO}_{4}$ & $55.4 \mathrm{ppm}$ \\
Manganese & $2.5 \mathrm{ppm}$ \\
Chrome & $0.14 \mathrm{ppm}$ \\
\hline
\end{tabular}

2.3. Logical Measurements. The organic content in PW was measured using a UV-spectrameter (UV-1800 Shimadzu, Japan) at a wavelength of $218 \mathrm{~nm}$, using n-hexane gas. A turbidimeter (Lovibond, SN 10/1471, Germany) was used to measure turbidity. The $\mathrm{pH}$ was measured by a $\mathrm{pH}$ meter (Model 2906, Jenway Ltd, UK).

2.4. $\mathrm{UV} / \mathrm{TiO}_{2}$ Bench-Scales Batch Reactor. Photocatalytic procedures squalor tests were performed in a $500 \mathrm{ml}$ glass batch reactor containing $250 \mathrm{~mL}$ PW stirred at $200 \mathrm{rpm}$ at different periods ranging between $30 \mathrm{~min}$ and $120 \mathrm{~min}$. The $\mathrm{pH}$ was adjusted by adding diluted $\mathrm{H}_{2} \mathrm{SO}_{4}$ or $\mathrm{NaOH}$.

2.5. Organic Content Tested by a UV-Spectrameter. $50 \mathrm{~mL}$ of PW and $5 \mathrm{ml}$ of $n$-hexane were added at $\mathrm{pH}=2$, shacked for $2 \mathrm{~min}$. Subsequently, after $10 \mathrm{~min}$, the PW solution was separated into two layers. The organic layer was not within the absorbance range; so, the organic content in PW was determined using a calibration curve.

2.6. Analytical Analysis and Kinetic Study. The organic removal percentage in $\mathrm{PW}$ was calculated using the following equation:

$$
\eta=\frac{C_{\text {initial }}-C_{\text {treated }}}{C_{\text {initial }}} \times 100 \% \longrightarrow,
$$

where $\eta$ is the organic removal efficiency; $C_{\text {initial }}$ is the initial organic concentration (ppm); and $C_{\text {treated }}$ is the final organic concentration (ppm).

The kinetics of the photocatalytic degradation rate of organic elimination were performed using the Langmuir-Hinshelwood kinetics model, according to the following equation, where a plot of $\ln (\mathrm{Co} / \mathrm{C})$ against time was drawn for each experiment to determine a straight-line relationship with slope (K1) of the pseudo-first-order rate constant, $\mathrm{k} 1\left(\mathrm{~min}^{-1}\right)[26,27]$.

$$
\ln \left[\frac{C_{O}}{C}\right]=K_{1} t
$$




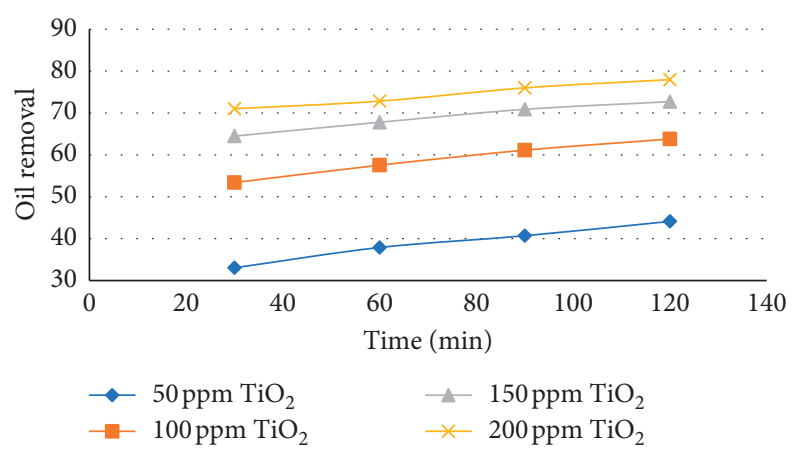

Figure 2: $\mathrm{TiO}_{2}$ effect on removal of $\mathrm{PW}$ at $\mathrm{pH}=6.5$.

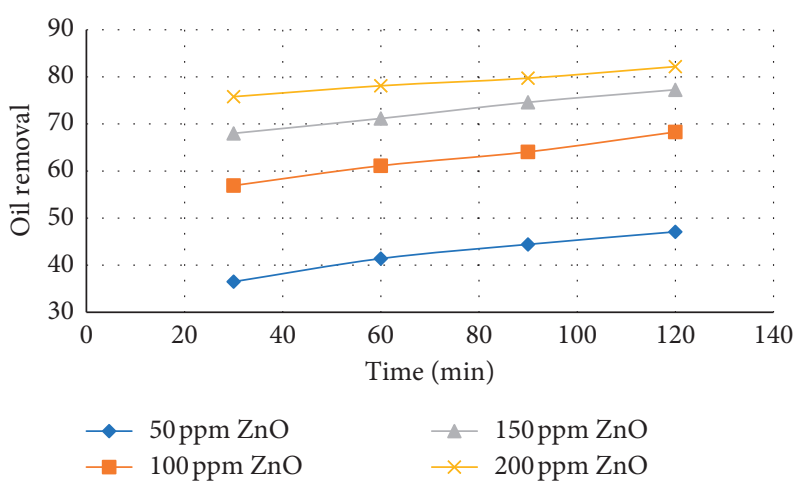

Figure 3: $\mathrm{ZnO}$ effect on removal of $\mathrm{PW}$ at $\mathrm{pH}=6.5$.

\section{Results and Discussion}

3.1. Catalysts Agent Effect. To examine the role of catalyst concentration on the photodegradation of PW, experiments were carried out at a wavelength less than visible light irradiation with different catalysts as shown in Figures 2 and 3 for $\mathrm{TiO}_{2}$ and $\mathrm{ZnO}$, respectively. The results indicate that $\mathrm{TiO}_{2}$ exhibits lower photocatalytic activity than $\mathrm{ZnO}$. A similar trend has been shown in previous findings with Biebrich scarlet dye as mentioned in [28]. Therefore, $\mathrm{ZnO}$ is better than $\mathrm{TiO}_{2}$, due to the higher band gap and superior quantum competence.

3.2. $p H$ Effect. The photocatalytic technique is significantly affected by $\mathrm{pH}$ values. The $\mathrm{pH}$ effect on the degradation of organic content in PW by photocatalytic processes is presented in Figure 4 for $\mathrm{TiO}_{2}$ and $\mathrm{ZnO}$, correspondingly. Increasing $\mathrm{pH}$ from 3 to 9 reduced the organic elimination from $96.4 \%$ to $65.4 \%$ by using $\mathrm{ZnO}$ and from $93.4 \%$ to $55.4 \%$ by using $\mathrm{TiO}_{2}$, respectively, which is in agreement with prior research [29]. As shown in Figure 4, that low $\mathrm{pH}$ causes higher organic degradation and increases the catalyst's active area and irradiation area [30]. Consequently, catalyst surface charge can be diverse at different $\mathrm{pH}$ levels, which will affect the particles adsorption on the catalyst surface which leads to degradation rate variation efficiently. Hence, the experiments succeeded in getting the optimum $\mathrm{pH}$ of the reaction mixture to approach the best decomposition of organic content in PW. The results were in contrast with [31] because the photodegradation rate decreased as $\mathrm{pH}$ increased for PW.

3.3. Irradiation Time Effect. This experiment focused on the effect of irradiation time influenced by the photocatalytic treatment to reach the highest possible elimination of organic content. Batch experiments were adopted to achieve the equilibrium by studying the relationship between organic elimination percentage and irradiation. Figures 5 and 6 elucidate that the process of organic elimination is slow and directly relative to the time for both agents $\mathrm{TiO}_{2}$ and $\mathrm{ZnO}$. This is due to free radicals that cause organic oxidation and increase removal of organic content, which is in agreement with the observations described in [10].

3.4. Kinetic Study. The pseudo-first-order models on catalytic agent tests are shown in Figures 7 and 8. Different concentrations of $\mathrm{TiO}_{2}(50,100$, and $150 \mathrm{ppm})$ and initial PW concentration of $142.5 \mathrm{mg} / \mathrm{L}$ were chosen to study the effect of $\mathrm{TiO}_{2}$ concentration on the kinetic coefficients of organic elimination percentage. According to appropriate experimental data rendering to equation (2), the $\mathrm{k} 1\left(\mathrm{~min}^{-1}\right)$ value was significant. Figure 7 shows $\ln (\mathrm{Co} / \mathrm{C})$ against lighting time using $\mathrm{TiO}_{2}$. The same trend is shown in Figure 8 using $\mathrm{ZnO}$.

The rate coefficients values in the model are provided in Table 2 using zinc oxide. $R^{2}$ is the pointer of how the equation can predict the results. The closer the value is to 1 , 


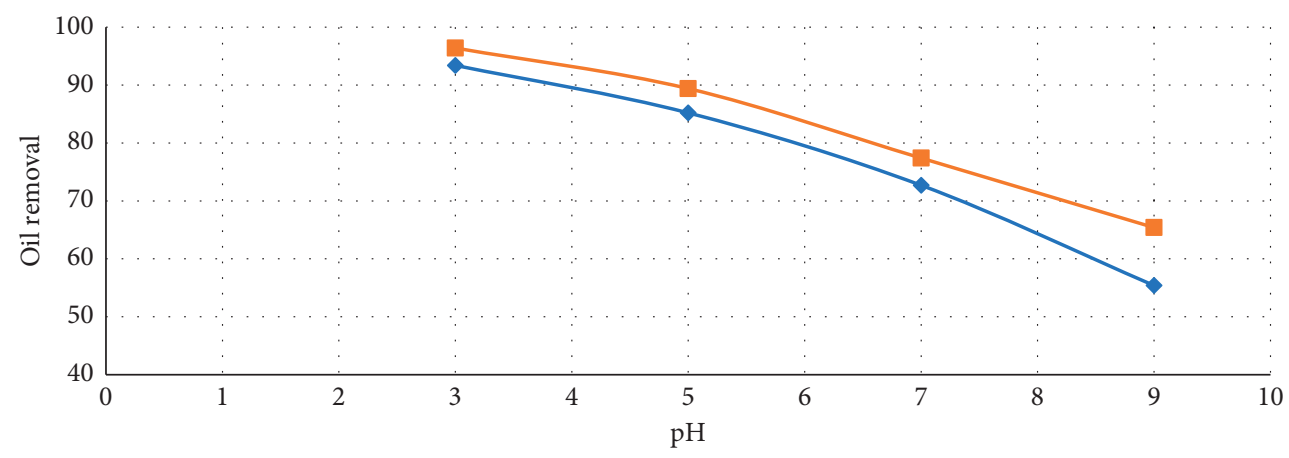

Figure 4: $\mathrm{pH}$ effect on removal of $\mathrm{PW}$ using $\mathrm{TiO}_{2}(150 \mathrm{ppm})$ and irradiation time $(120 \mathrm{~min})$.

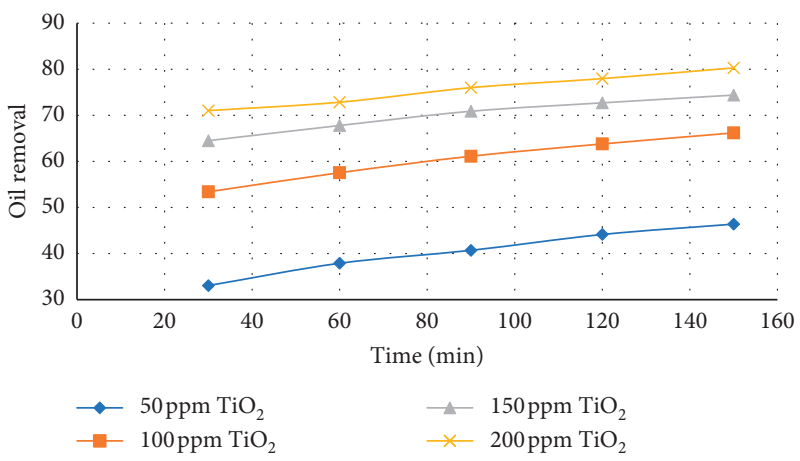

Figure 5: Irradiation time effect on removal of $\mathrm{PW}$ by adding $150 \mathrm{ppm} \mathrm{TiO} 2$ at $\mathrm{pH}=6.5$.

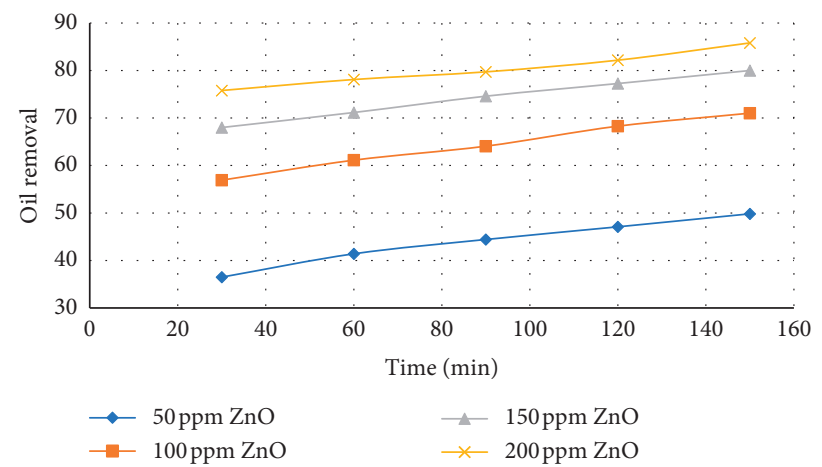

FIgURE 6: Irradiation time effect on removal of $\mathrm{PW}$ by adding $150 \mathrm{ppm} \mathrm{ZnO}$ at $\mathrm{pH}=6.5$.

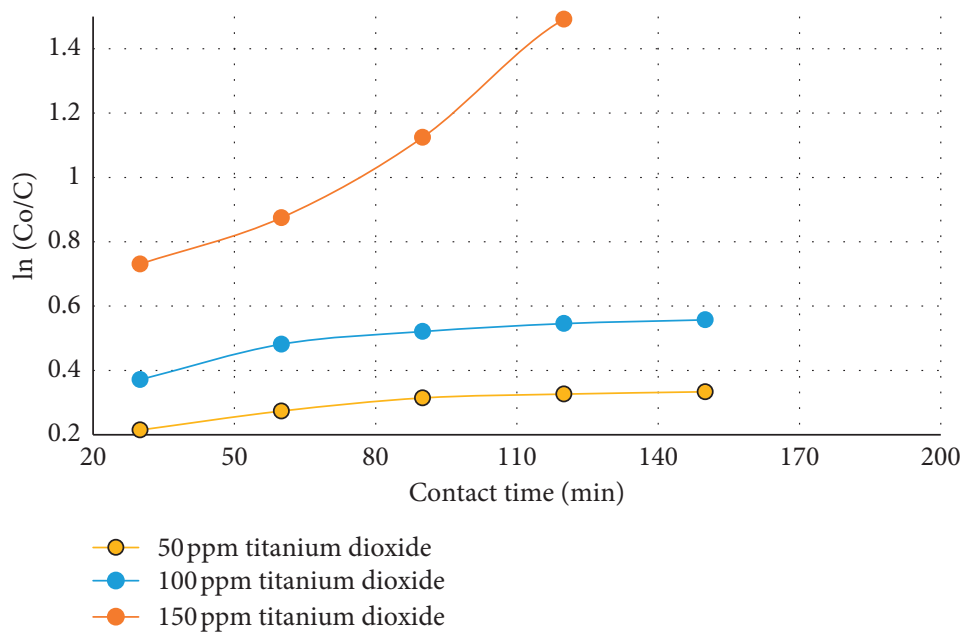

Figure 7: Pseudo-first-order model for degradation of $\mathrm{PW}$ using $\mathrm{TiO}_{2}$ at $\mathrm{pH}=6.5$. 


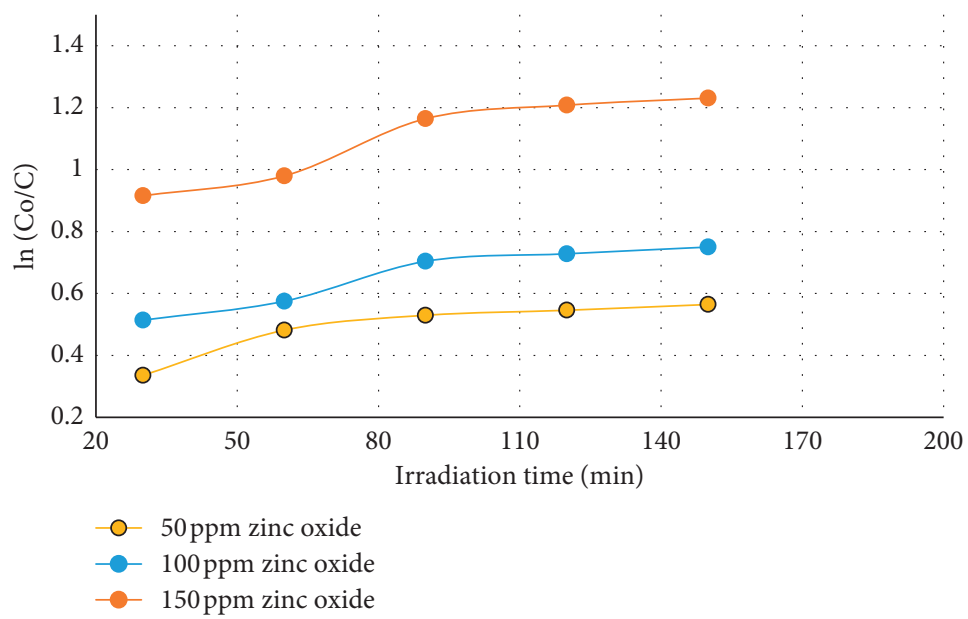

Figure 8: Pseudo-first-order model for degradation of $\mathrm{PW}$ using $\mathrm{ZnO}$ at $\mathrm{pH}=6.5$.

TABle 2: Rate constants using ZnO.

\begin{tabular}{lcc}
\hline $\mathrm{ZnO}$ & $\mathrm{K}_{1} \min ^{-1}$ & First-order \\
& 0.0017 & $R^{2}$ \\
\hline 50 & 0.0021 & 0.7987 \\
100 & 0.0029 & 0.9 \\
150 & & 0.91 \\
\hline
\end{tabular}

the better and more appropriate the model is. From Figures 7 and 8 , it is clear that $\mathrm{ZnO}$ is more effective than $\mathrm{TiO}_{2}$.

Figure 8 shows that the rate constant $K_{1}$ increases gradually to a maximum of $2.9 \times 10^{-3} \mathrm{~min}^{-1}$ at an optimum concentration of $150 \mathrm{mg} / \mathrm{L} \mathrm{ZnO}$, which coincides with [28].

\section{Conclusion}

The organic degradation in PW is affecting the durability of steel piles. Different catalysts of $\mathrm{TiO}_{2}$ and $\mathrm{ZnO}$ were tested in the presence of an energy source. $\mathrm{ZnO}$ showed a high absorption property that is good enough to absorb organics. Therefore, it is preferred to $\mathrm{TiO}_{2}$.

The degradation kinetics of organic content in PW follow first-order kinetics. However, photocatalytic processes can be adopted for the degradation of organic content from PW. This study indicates that the service life of the steel piles in the contaminated soil can be maintained using the catalyst.

\section{Data Availability}

No data were used to support this study.

\section{Conflicts of Interest}

The authors declare that they have no conflicts of interest.

\section{References}

[1] R. Hosny, M. Fathy, M. Ramzi, T. Abdel Moghny, S. E. M. Desouky, and S. A. Shama, "Treatment of the oily produced water (OPW) using coagulant mixtures," Egyptian Journal of Petroleum, vol. 25, no. 3, pp. 391-396, 2016.
[2] M. K. Ibrahim, A. A. Al-Hassan, and A. S. Naje, "utilisation of cassia surattensis seeds as natural adsorbent for oil content removal in oilfield produced water," Journal of science and Technology, vol. 27, no. 4, 2019.

[3] A. A. Aziz and W. M. A. W. Daud, "Oxidative mineralisation of petroleum refinery effluent using Fenton-like process," Chemical Engineering Research and Design, vol. 90, no. 2, pp. 298-307, 2012.

[4] S. Jiménez, M. M. Micó, M. Arnaldos et al., "Integrated processes for produced water polishing: enhanced flotation/ sedimentation combined with advanced oxidation processes," Chemosphere, vol. 168, pp. 309-317, 2017.

[5] M. Fathy, M. El-Sayed, M. Ramzi, and O. H. Abdelraheem, "Adsorption separation of condensate oil from produced water using ACTF prepared of oil palm leaves by batch and fixed bed techniques," Egyptian Journal of Petroleum, vol. 27, no. 3, 2017.

[6] A. S. Jafer and A. A. Hassan, "Removal of oil content in oilfield produced water using chemically modified kiwi peels as efficient low-cost adsorbent," Journal of Physics: Conference Series, vol. 1294, p. 72013, 2019.

[7] A. Fakhru'l-Razi, A. Pendashteh, L. C. Abdullah, D. R. A. Biak, S. S. Madaeni, and Z. Z. Abidin, "Review of technologies for oil and gas produced water treatment," Journal of Hazardous Materials, vol. 170, no. 2, pp. 530-551, 2009.

[8] T. D. Kusworo, N. Aryanti, D. P. Qudratun, and D. P. Utomo, "Oilfield produced water treatment to clean water using integrated activated carbon-bentonite adsorbent and double stages membrane process," Chemical Engineering Journal, vol. 347, pp. 462-471, 2018.

[9] I. Velo-Gala, J. J. López-Peñalver, M. Sánchez-Polo, and J. Rivera-Utrilla, "Comparative study of oxidative degradation of sodium diatrizoate in aqueous solution by $\mathrm{H} 2 \mathrm{O} 2 / \mathrm{Fe} 2+$, $\mathrm{H} 2 \mathrm{O} 2 / \mathrm{Fe} 3+, \mathrm{Fe}$ (VI) and UV, H2O2/UV, K2S2O8/UV," Chemical Engineering Journal, vol. 241, pp. 504-512, 2014.

[10] H. T. Naeem, A. A. Hassan, and R. T. Al-khateeb, "Wastewater-(Direct red dye) treatment-using solar Fenton process," Pharmaceutical Sciences and Research, vol. 10, no. 9, pp. 2309-2313, 2018.

[11] A. A. Hassan and K. M. Mousa Al-zobai, "Chemical oxidation for oil separation from oilfield produced water under UV irradiation using Titanium dioxide as a nano-photocatalyst by batch and continuous techniques," International Journal of Chemical Engineering, vol. 2019, Article ID 9810728, 8 pages, 2019. 
[12] R. M. Alkhalssi, E. A. Saeed, and M. G. Khalid, "Treatment of emulsified oil in produced water from oil wells by adsorption on to corn-cob as sorbent," Al-Nahrain University, College of Engineering Journal (NUCEJ), vol. 17, no. 1, pp. 83-90, 2014.

[13] H. T. Naeem and A. A. Hassan, "Effectiveness \& economy of sawdust wood adsorbents in removing anionic dyes of aqueous solutions," Pakistan Journal of Biotechnology, vol. 15, pp. 311-320, 2018.

[14] M. Mahdavi, A. Ebrahimi, H. Azarpira, H. R. Tashauoei, and A. H. Mahvi, "Dataset on the spent filter backwash water treatment by sedimentation, coagulation and ultra filtration," Data in Brief, vol. 15, pp. 916-921, 2017.

[15] D. Huang, C. Hu, G. Zeng et al., "Combination of Fenton processes and biotreatment for wastewater treatment and soil remediation," Science of The Total Environment, vol. 574, pp. 1599-1610, 2017.

[16] J. J. Rueda-Márquez, M. Sillanpää, P. Pocostales, A. Acevedo, and M. A. Manzano, "Post-treatment of biologically treated wastewater containing organic contaminants using a sequence of $\mathrm{H} 2 \mathrm{O} 2$ based advanced oxidation processes: photolysis and catalytic wet oxidation," Water Research, vol. 71, pp. 85-96, 2015.

[17] A. A. Hassan and H. T. Naeem, "A comparative study of chemical material additives on polyacrylamide to treatment of waste water in refineries," IOP Conference Series: Materials Science and Engineering, vol. 518, 2019.

[18] K. M. Mousa and A. A. Al-Hasan, "Oilfield produced water treatment by coagulation/flocculation processes," in Proceedings of the Second Conference of Post Graduate Researches (CPGR'2017) College of Engineering, Baghdad, Iraq, October 2017.

[19] A. B. M. S. Abeish, Enhanced photocatalytic degradation of biorefractory pollutants in petroleum refinery wastewater, Ph.D. Thesis, Curtin University, Bentley, Perth, Australia, 2015.

[20] V. T. Voort, M. Suleiman, and S. Sritharan, Design and Performance Verification of Ultra-High Performance Concrete Piles for Deep Foundations, Iowa Highway Research Board, IHRB Project TR-558, Ames, Iowa, 2008.

[21] H. K. Sultan and I. Alyaseri, "Effects of elevated temperatures on mechanical properties of reactive powder concrete elements," Construction and Building Materials, vol. 261, Article ID 120555, 2020.

[22] O. A. Qasim and H. K. Sultan, "Experimental investigation of effect of steel fiber on concrete construction joints of prism," IOP Conference Series: Materials Science and Engineering, vol. 745, Article ID 012170, 2020.

[23] J. M. Poyatos, M. M. Muñio, M. C. Almecija, J. C. Torres, E. Hontoria, and F. Osorio, "Advanced oxidation processes for wastewater treatment: state of the art," Water, Air, and Soil Pollution, vol. 205, no. 1-4, p. 187, 2010.

[24] T. Yonar, "Decolorisation of textile dyeing effluents using advanced oxidation processes," in Advances in Treating Textile EffluentInTechopen, London, UK, 2011.

[25] S. S. Kalra, S. Mohan, A. Sinha, and G. Singh, "Advanced oxidation processes for treatment of textile and dye wastewater: a review," in Proceeding of the 2nd International Conference on Environmental Science and Development, vol. 4, pp. 271-275, Mumbai, India, January 2011.

[26] A. H. Jawad, N. S. A. Mubarak, M. A. M. Ishak, K. Ismail, and W. I. Nawawi, "Kinetics of photocatalytic decolourization of cationic dye using porous $\mathrm{TiO} 2$ film," Journal of Taibah University for Science, vol. 10, no. 3, pp. 352-362, 2016.
[27] M. A. Hassaan, A. El Nemr, and F. F. Madkour, "Testing the advanced oxidation processes on the degradation of Direct Blue 86 dye in wastewater," The Egyptian Journal of Aquatic Research, vol. 43, no. 1, pp. 11-19, 2017.

[28] S. K. Kansal, A. Hassan Ali, and S. Kapoor, "Photocatalytic decolorization of biebrich scarlet dye in aqueous phase using different nanophotocatalysts," Desalination, vol. 259, no. 1-3, pp. 147-155, 2010.

[29] J. R. Alvarez-Corena, J. A. Bergendahl, and F. L. Hart, "Advanced oxidation of five contaminants in water by UV/ TiO2: reaction kinetics and byproducts identification," Journal of Environmental Management, vol. 181, pp. 544-551, 2016.

[30] L. Karimi, S. Zohoori, and M. E. Yazdanshenas, "Photocatalytic degradation of azo dyes in aqueous solutions under UV irradiation using nano-strontium titanate as the nanophotocatalyst," Journal of Saudi Chemical Society, vol. 18, no. 5, pp. 581-588, 2014.

[31] N. Deepa, P. Meghna, and S. Kandasamy, "Experimental studies on decolorisation of malachite dye using continuous photocatalytic reactor," International Research Journal of Environmental Sciences, vol. 3, no. 3, pp. 14-21, 2014. 